\title{
Landscape Conflicts-A Theoretical Approach Based on the Three Worlds Theory of Karl Popper and the Conflict Theory of Ralf Dahrendorf, Illustrated by the Example of the Energy System Transformation in Germany
}

\author{
Olaf Kühne \\ Department of Geography, Eberhard Karls University, 72074 Tübingen, Germany; olaf.kuehne@uni-tuebingen.de \\ Received: 26 June 2020; Accepted: 13 August 2020; Published: 20 August 2020 \\ check for
updates
}

\begin{abstract}
On the basis of Karl Popper's Three Worlds Theory, a theoretical approach to landscape can be derived, which includes the physical foundations of landscape (Landscape 1), the individual construction and emotions drawn from and placed upon landscape (Landscape 2), and social conventions regarding landscape (Landscape 3). These three landscape dimensions are connected via Landscape 2, which also provides an approach for the systematic investigation of the relations between the dimensions. Ralf Dahrendorf's conflict theory in turn serves as a theoretical framework for when the different connections develop in a conflictual way and how these can be regulated. Dahrendorf sees a principled productivity of conflicts, providing they are settled fairly. On the basis of the conditions he has developed for just such a conflict settlement, the implementation of the energy system transformation is examined against the background of its consequences for the landscape, with the result that essential conditions for an orderly settlement of conflicts are not fulfilled, thereby contributing to the polarization of society.
\end{abstract}

Keywords: Three Worlds Theory; conflict theory; energy system transformation; wind power; conflict; Karl Popper; Ralf Dahrendorf

\section{Introduction}

Landscape conflicts have been the subject of scientific research for quite some time (among many: [1-3]). Particularly with the physical manifestation of the energy system transformation, conflicts over landscape have taken on new topicality [4-9]. The present paper is concerned with the investigation of the origin, the course, and the intensity of landscape conflicts. In the following, landscape is first of all understood as a social construction (socially shared interpretations and evaluations), which is individually updated and projected by the individual into physical spaces. Landscape conflicts are understood to be conflicts that arise from different interpretations, evaluations, and demands on landscape, from the relationships between individuals and social interpretations and evaluations, between individual interpretations, evaluations and demands on physical spaces, and that are carried out between individuals (i.e., supra-individual). Conflicts arise when the physical manifestations of the energy system transformation deviate from collective or individual notions of landscape. In order to be able to understand the conflictive relationships between the material world and individual and societal ideas, two theoretical approaches will be used in the following: The Three Worlds Theory of the philosopher and science theorist Karl Popper (1904-1994; [10,11]) and the conflict theory of the sociologist, and Popper student, Ralf Dahrendorf (1929-2009; [12,13]). The Three Worlds Theory serves as a basis for the analytical differentiation of landscape into different levels as well as the 
various connections of the different levels. The conflict theory of Ralf Dahrendorf, in turn, serves as a theoretical framework should the different connections develop in a conflictual way and illustrates how these can be regulated. The central approach of the essay is to emphasize in the first step in which form landscape conflicts within and between individual constructions and social conventions based on observation (especially changes) in material space develop. In the second step, the question of how landscape conflicts can be regulated is addressed. Since conflicts over landscape take place on the three levels mentioned above (and between them), the understanding of conflicts over landscape proposed here is a combination of the two theories. This involves a sociological operationalization of Karl Popper's philosophy, which follows in the tradition of Popper's student Ralf Dahrendorf, who in numerous publications classified Popper's world of thought into social and political science questions.

The presentation of landscape conflicts is based on the example of the energy system transformation in Germany, which has been pushed forward by changing governments at least since the reactor disaster in Fukushima [14,15]. Here the quintessence of numerous, mostly empirical studies on conflicts in the context of energy system transformation in Germany and their classification in the theoretical framework described above is presented. The conclusion deals with the question of the extent to which the chosen theoretical frameworks are suitable for contributing to the understanding of landscape conflicts, in particular, and landscape processes in general (with focused reference to Karl Popper's Three Worlds Theory).

\section{The Theoretical Framework I: Landscape framed with Karl Popper's Three Worlds theory}

When we speak of 'landscape', it is usually understood as an object, in the course of increasing significance of constructivist perspectives, but also as a social construction-and more rarely, an individual construction. The discomfort with this dualistic world view brought non-representational theories into landscape research, such as actor-network theory, assemblage theory, and even an update of phenomenology (among many: [16-18]). The following approach to landscape research based on Karl Popper's Three Worlds Theory can also be placed in this context $[19,20]$.

Karl Popper describes 'World 1' as a world of living and non-living bodies. With 'World 2' he describes the content of consciousness, individual thoughts, and feelings. With 'World 3', "all planned or intended products of human mental activity" [11]. The 'reality' of these three worlds is not strictly separated, but rather hybrid, so a building is part of both 'World 1' and 'World 3'. With this approach, Popper sought to create an alternative to the materialistic worldview that only recognizes 'World 1 ', the immaterialistic worldview that only recognizes 'World 2', as well as the dualistic worldview that recognizes 'Worlds 1 and 2' as 'real', by adding 'World 3', "the world that anthropologists call 'culture' [11]. The abstract entities of world 3 (including scientific theories, concepts, mathematical formulas, but also socially shared ideas about certain "things") have an effect on world 2 (socialization) and, via the individual world 2, also on world 1 (see Figure 1). Karl Popper's Three Worlds Theory became partly the subject of fierce criticism. In the approach presented here, the division into three worlds (later three landscapes) serves as an analytical basis for understanding social conflicts, so the criterion for the use of the theory is less on ontological truth but rather on analytical suitability for explaining landscape conflicts (which ultimately take place between the worlds). The criticism that Popper's approach does not separate the worlds categorically enough can also be seen as of little relevance for landscape research, as this often deals with the hybrid formations of 'landscapes' (see in this complex of topics: [16-19]). 


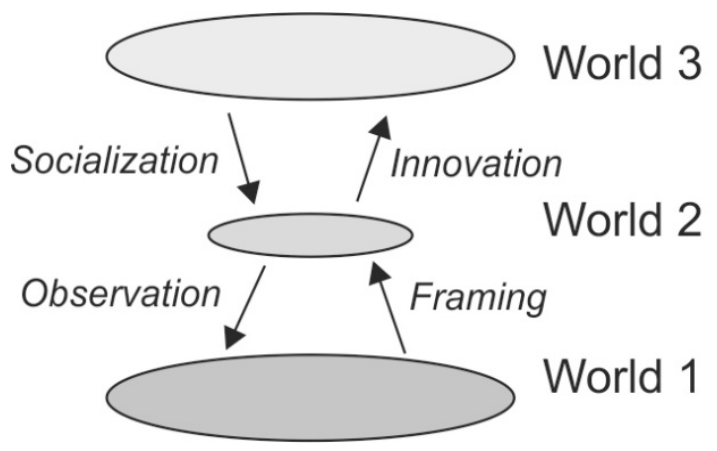

Figure 1. The three worlds of Karl Popper and their connections to each other. Central importance is therefore given to world 2 (own illustration).

Popper's terminology applied to landscape can be understood as Landscape 3 as the social construction of landscape, Landscape 2 as individual conceptions and attributions, and Landscape 1 as the physical objects used for the social or individual construction of landscape. The three landscapes are interdependent: Essential components of Landscape 2 are conveyed from Landscape 3, since only in part do direct experiences of Landscape 1 form the basis for the formation of Landscape 2; rather, it is to a large extent the subject of the socialization of social ideas, interpretations, and evaluations (see here among many others: [21-23]). Through the mediation of Landscape 2, because only individuals have a body (as part of World 1), Landscape 3 also has an effect on Landscape 1; people inscribe their ideas onto physical spaces. Landscape 2 does not only act on Landscape 1 as a transmission belt of the patterns of imagination, interpretation, and evaluation of Landscape 3; Landscape 2 can act on Landscape 3 by formulating alternative interpretations, evaluations, and ideas, including the possibility of anchoring them there (see here in general: [24,25], illustration: Figure 2).

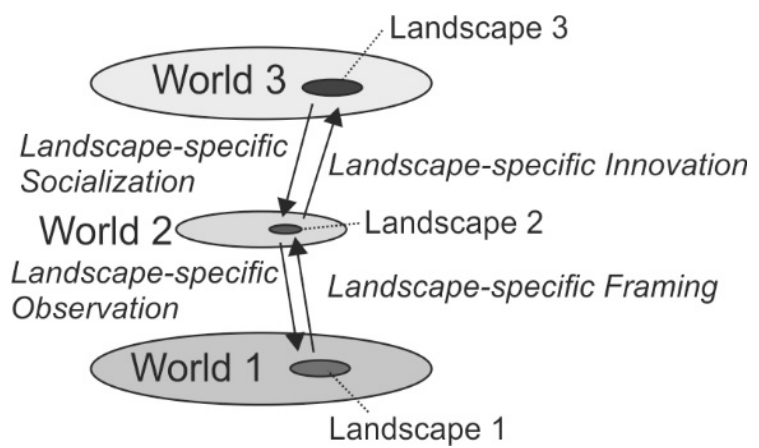

Figure 2. The landscapes 1, 2, and 3 as parts of the worlds 1, 2, and 3, as well as the landscape specific connections between the landscapes 1, 2, and 3 (own illustration).

As it turns out: Landscapes 1, 2, and 3 are not only changeable, they are constitutively dependent on change. Without natural processes and societal changes, there would be no Landscape 1, as Landscape 2 evolves and changes in relation to Landscapes 1 and 2, and in recent decades the processes of change as well as the differentiation of Landscape 3-not least in feedback with the processes of change within Landscape 1-have moved into the center of scientific interest (among many: [26,27]), whereby Landscape 3 is subject to clear cultural differences [28,29].

The Landscapes 1, 2, and 3 can be further differentiated in terms of their origin. They are designated with the suffix letters $a, b$, and c (in extension of [24,30]). The classification according to letters shown here is derived inductively from empirical studies (quantitative, but especially qualitative: [26,31-33]). These are the 'native normal landscape' (suffix a), the 'stereotypical' or 'common-sense landscape' (suffix b), and 'expert special knowledge' on landscape (suffix c). The 'native normal landscape', as Landscape $2 \mathrm{a}$, is created in one's initial landscape experiences, but also in the form of an individual 
'landscape biography' through different confrontations with different Landscapes 1 , through changes of residence, travelling, and experiences in the virtual world, etc. [34-36]. If Landscape 2a is generalized, e.g., by sharing it with others, Landscape $3 a^{\prime}$ is created, the single apostrophe (') denotes the derivation, i.e., the creation of this sub-landscape does not occur primarily on this level. Landscape $2 b^{\prime}$ denotes the individual expression of the common-sense understanding that is Landscape $3 \mathrm{~b}$ of landscape, which is conveyed in school lessons, through feature films and documentaries, literature, the Internet, and so forth. Here, the individual learns how to describe and evaluate World 1 as a 'landscape' without having to fear the loss of social recognition. $[23,37,38]$. A selective aspect of the individual development of Landscape 2 is the incorporation of 'expert special knowledge' in the form of vocational training and especially scientific studies (Landscape 3c; [35]), whereby Landscape $2 c^{\prime}$ is created. It is precisely in this context that persons as bearers of Landscape $2 c^{\prime}$ are able to influence Landscape $3 c$ (this essay is an attempt to do so). According to the terminology used here, Landscape $2 c^{\prime \prime}$ emerges from this feedback as a double derivation (Figure 3).

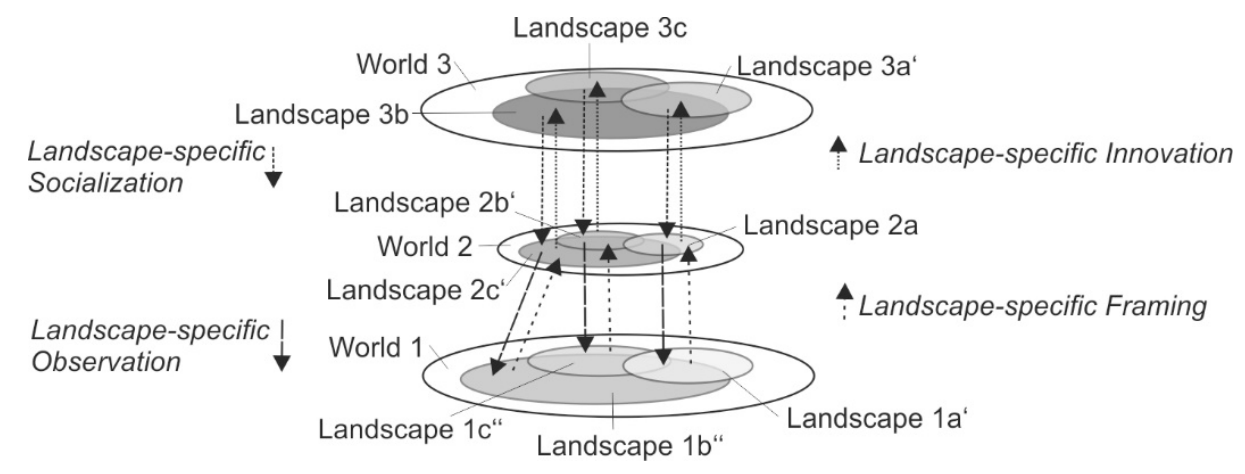

Figure 3. The differentiated construction of landscape from elements native normal landscape-a, stereotype-sustainability-915708 - added rev, and in relation to expert special knowledge- $\mathrm{c}$ on the levels of Landscapes 1, 2, and 3. Additionally, derivations (') and double derivations (") are listed, whereby also the constitutive levels become clear (own illustration).

Landscape 2 represents - in its various manifestations-the central element of the connection between Landscape 3 and Landscape 1, but also between Landscape 3 and Landscape 2a via Landscape 2 , and Landscape 1 is only perceived by those who have learned to make it accessible to it, i.e., who have developed Landscape $2 \mathrm{a}$, into which Landscape $3 \mathrm{~b}$ and perhaps $3 \mathrm{c}$ have been introduced. However, the patterns of interpretation of Landscape 3 do not give birth to themselves but are dependent on the actualization generated by the bearers of Landscape 2 .

Two things become clear from these remarks: Landscape change does not only take place on the three levels of landscape, but the changes in the relationships between Landscape 2 and Landscape 1 , and between Landscape 2 and Landscape 3, also have a constitutive significance. These changes are not only normal, but often conflictual, as different norms, interpretations, and valuations of landscape compete with each other. The great importance given to the individual illustrates the liberal foundational position of the approach, combined with the preference for a society that is open to change [39] and open to the productivity of conflicts, thus anticipating a central element of Ralf Dahrendorf's conflict theory.

\section{The Theoretical Framework II: The Conflict Theory of Ralf Dahrendorf}

The conflict theory of Ralf Dahrendorf deals with social conflicts [12] "A conflict should be called social when it can be derived from the structure of social units, i.e., when it is supra-individual". Ralf Dahrendorf develops his conflict theory in contrast to the structural functionalism of Talcott Parsons [40] and the historical materialism of Karl Marx [41] as an operationalization of Karl Popper's remarks on the open society. The implied social model of structural functionalism-as Dahrendorf 
criticizes [42] —is "a relatively stable system of parts whose function is determined in relation to the system", whereby it is critical of change and evaluates social conflicts as principally dysfunctional. The rejection of this position is based, following Karl Popper, on a socio-political basic position: "Liberalism is necessarily a philosophy of change" [25]. Dahrendorf associates the principally positive interpretation of conflictual social change with Marx, but he rejects Marx' focus on revolutions, as they are always associated with bloodshed, which-here he again follows Karl Popper — must be avoided. He also rejects Marx's teleological notion of a utopian final society. Referring to Karl Popper, he formulates the difficulty of designing the future as follows: Whenever human beings "design the future-and designing the future is perhaps one of the great human tasks-we make an attempt, which can also be a mistake" [43], which ultimately means that as many answers as possible to the questions of the time should be made available, both politically and scientifically [11,44].

Ralf Dahrendorf's conflict theory appears to be particularly suitable for the theoretical framing of landscape conflicts for several reasons: It focuses on social conflicts (i.e., supra-individual conflicts) within societies and deals with hierarchical conflicts as well as conflicts between groups with similar power structures. In doing so, it shows a high degree of actualization: Although the basic features of Dahrendorf's conflict theory date back to the 1950s, he updated it repeatedly until his death in 2009 and used it to interpret more recent conflicts (such as the Northern Ireland conflict). In addition, he anticipated aspects of more recent conflict theories (such as postmodern ones) by pointing out the creation of identity through conflict in the early stages of the development of his conflict theory (see in this context: [45-48]).

Dahrendorf recognizes a central element of society in social conflicts: "The thought that there is conflict may be unpleasant and disturbing wherever we find social life: it is nevertheless inevitable for our understanding of social problems" [42]. In this respect, social conflicts are embedded in a structure of social change, the possible influence of individuals and power, because:

1. Every society is subject to constant and universally present change (ubiquity of change).

2. Every society knows social conflicts (ubiquity of the conflict).

3. Each member of the society contributes to the change of the society (ubiquity of productivity).

4. Every society is characterized by power relations in which members of the society exercise power over other members (ubiquity of domination; e.g., [12,45,46]).

Social conflicts follow a regularity. Dahrendorf identifies three phases of conflict development [12]:

- The emergence of the structural starting position. Subsets in society, which he calls 'quasi-groups', have the same latent interests. By 'latent interests' he means "all position-related behavioral orientations (role expectations), which establish a contradictory relationship between two aggregates of positions without the bearers of the positions necessarily being aware of it" [49].

- The awareness of latent interests. Here a group formation takes place, which is coupled with an increasing presence to the outside, because "every social conflict pushes to the outside, to the visible precipitation" [12].

- The organized nature of the conflict. The organized parties to the conflict "with a visible identity of their own" [12] The conflict takes on a dichotomized structure, and the pros and cons do not tolerate differentiation.

Conflicts vary according to 'intensity' and 'violence' [12]. Intensity refers to the social relevance of the conflict: "It is high when a lot depends on it for the parties involved, i.e., when the costs of defeat are high" [12]. The degree of violence, on the other hand, ranges from a non-binding discussion to a world war. As explained above, Dahrendorf (following Popper) aims to keep the brutality of conflicts low on the one hand, and to increase their potential for enhancing life chances on the other hand, whereby he understands life chances "first of all as chances of choice, options. They demand two things, rights of participation and an offer of activities and goods to choose from" [21]. Those choices must be connected to meaning. With regard to dealing with conflicts, three possibilities can be found $[12,13]$. 
The suppression of conflicts is connected with the fact that the conflicts cannot be applied, which increases their intensity and subsequently they break out violently. The solution of conflicts would mean to eliminate their social causes (especially the unequal distribution of power), which would be utopian and therefore also rejected by Dahrendorf. Dahrendorf favors the third way of dealing with conflicts-their settlement. The successful resolution of conflicts depends on four preconditions and two institutional frameworks: Firstly, the conflict contradictions must be recognized as a legitimate dimension of normality, not as a state contrary to the norm. Secondly, conflict resolution refers to the characteristics of the conflict, not to its causes. The efficiency of conflict resolution is positively influenced by a high degree of organization of the conflict parties (third). Fourthly, the success of conflict resolution depends on compliance with certain rules. These rules must not favor any of the conflicting parties, i.e., the conflicting parties are to be regarded as equal (therefore certain pre-defined procedural rules must be observed). The institutional framework describes (firstly) the existence of a third party that, on the one hand, makes generally binding rules on how to deal with conflicts and, on the other hand, has the possibility of ending the conflict externally if necessary: Dahrendorf [50] describes this as "freedom under the protection of the law". A second institutional prerequisite is the imputation of responsibility for decisions, in liberal democracy in particular the regular review of the satisfaction of the elected representatives' management record by the electorate [51].

In the context of the modernization of society, marked by greater individualization and differentiation, the tendency to approach things rationally, the increasing appreciation of the person, the increase in social prosperity, and so forth, the reduction in the importance of 'great' social conflicts (such as the class struggle of Marx) that took place with great intensity and brutality, and a multitude of micro-conflicts with limited intensity and brutality ([13,52,53]; a more detailed presentation and classification of Dahrendorf's conflict theory can be found at: [48,54-56]).

This theoretical framework for Landscapes 1, 2, and 3 (based on Karl Popper) and Ralf Dahrendorf's conflict theory will form the framework for the analysis of landscape conflicts in the context of the energy system transformation (especially in Germany).

\section{Landscape Conflicts in the Energy System Transformation}

In recent years energy landscapes have been [57], not only in Germany, the subject of intensive conflicts, which are often rooted in the different patterns of interpretation and evaluation applied to Landscape 1. But before these are subjected to a more intensive examination, it is necessary to outline some basic features of energy system transformation in Germany in order to establish the political context of the conflicts surrounding energy system transformation and their relation to landscape.

The concept of 'energy system transformation' was made discursive by a book from the Öko-Institut Freiburg in 1980 entitled "Energiewende: Growth and prosperity without oil and uranium" [58]. With the introduction of the Electricity Supply Act of 1990, the systematic expansion of renewable energies began, the Renewable Energy Sources Act in 2000 accelerated the expansion and the phase-out of nuclear energy, approved in the same year, making the expansion of renewable energies even more urgent $[15,59,60]$ whereby nuclear power plant operators were granted an extension of the operating life of nuclear power plants in 2010 of 8 years (for older) and 14 years (for younger) [53,61,62]. Following the reactor disaster in Fukushima (Japan) in March 2011, it was decided to phase-out nuclear power as part of the energy supply by 2022, but the targets for implementing energy system transformation are more ambitious: renewable energies are to account for $40-45 \%$ of gross electricity consumption by 2025 and $55-60 \%$ by 2035 [63]. In the past 20 years, the share of renewable energies, especially wind power, has increased massively in Germany (Figure 4), which is associated with significant changes in Landscape 1. 


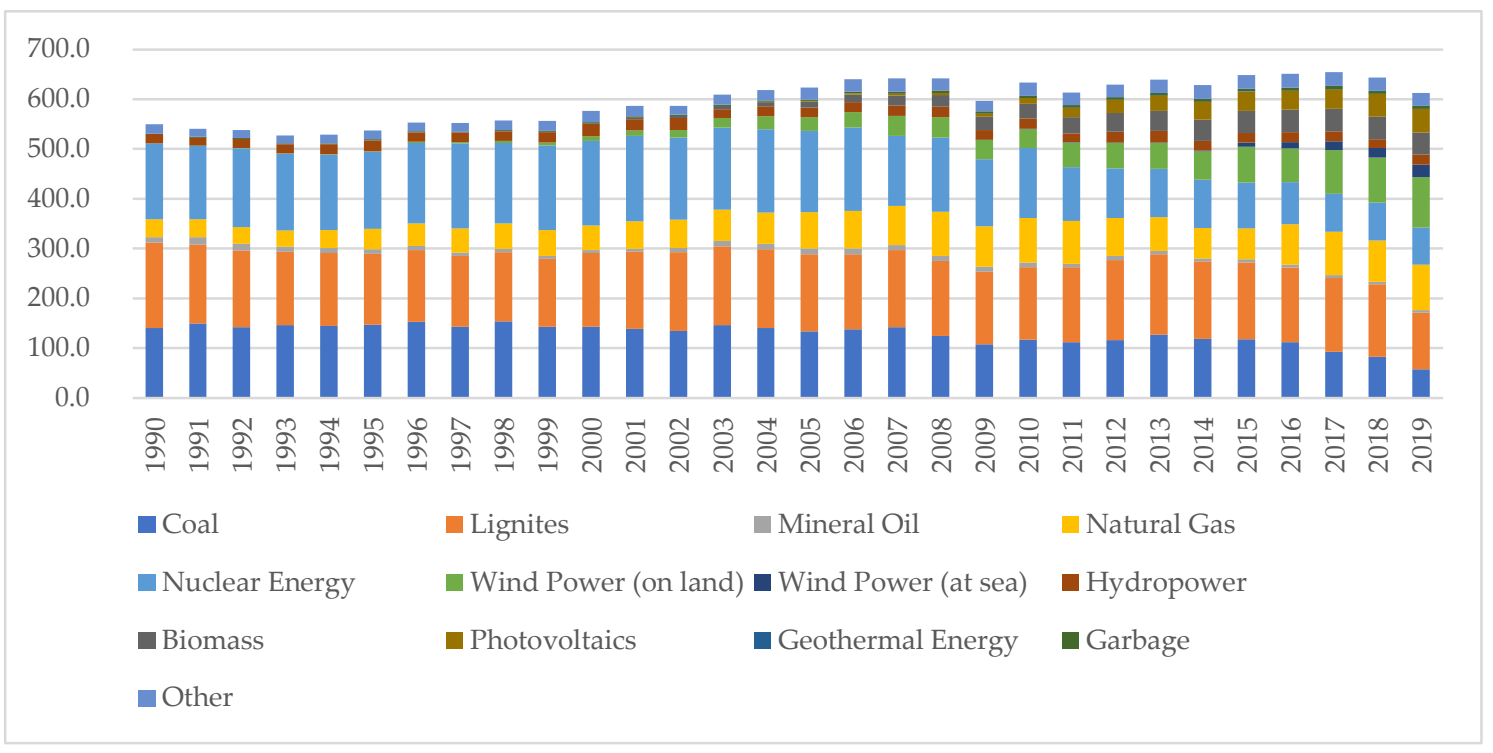

Figure 4. Gross electricity generation by energy source-in TWh in Germany between 1990 and 2019. (own illustration; data basis: Bundesministerium für Wirtschaft und Energie [64]).

However, these changes in Landscape 1 are not limited to the presence of wind power plants, because the energy transition means—after Fordist centralization to large power plants [65]—a renewed decentralization of energy production $[66,67]$. This is not evenly distributed according to renewable energy sources in Germany: In the windy north of the country, electricity generation from wind power plants dominates, while in the south, where the number of hours of sunshine is greater, there is an increased expansion of photovoltaic plants. Accordingly, the expansion of the electricity transmission networks is being driven forward, with around $8000 \mathrm{~km}$ of overhead or underground lines being implemented or planned as a result of the energy system transformation, combined with additional landscape-related conflicts (more [68-71]). As a result of the large physical presence in Landscape 1 of the plants for the generation and transmission of renewable electricity, the topic of landscape has a high presence in citizens' initiatives against these plants (Figure 5). The results presented here were each part of studies that dealt with the genesis, characteristics, and emergence of hegemonic discourses in relation to the expansion of plants for the generation and transmission of renewable electricity. These studies clearly show the importance of landscape norms (Landscapes 3a' and 3b) on the one hand, but also- on the basis of participant observation and qualitative interviews-the low level of political and legal operationalizability. This in turn leads to a sclerotization of the dichotomy of the conflict parties (this will be discussed in more detail later). Motives for the conservation of Landscape $1 a^{\prime}$ and $1 b^{\prime \prime}$ are 'masked' by arguments that are accepted by the courts, especially with regard to species protection.

The changes of Landscape 1 in the context of the energy system transformation encounter not only differentiated aesthetic and normative implications, for example in Landscape $2 a, 3 b$, and $3 c$, as discussed in the previous sections, but also increasing differentiation within them. In other words, demands on Landscape 1 differentiate themselves with social differentiation and individualization [65,72-74]. First to the different normative demands on Landscape 1: The normative content of Landscape 2a and - if validated by consensus-3a' is directed towards familiarity (Figure 6). The normative content of Landscape $3 b$ and (if individually updated) $2 b^{\prime}$ is primarily directed at the observance of social aesthetic norms, secondarily at moral norms, such as 'what is good, what is natural' $[75,76]$. Thus, if landscape is evaluated in Landscape $2 a\left(3 a^{\prime}\right)$ mode, any change from and in Landscape 1 that is interpreted as significant is described as contrary to the standard. In the construction mode of Landscape $2 b^{\prime}$, however, this is only if these changes contradict stereotypical social expectations. From the perspective of Landscape 2a supra-individual Landscape 3a', the construction of a wind farm is therefore viewed critically, because it contradicts the normative stability expectations 
of Landscape 1. If the interpretation is based on Landscape $3 b$ or $3 b^{\prime}$, it does not contradict aesthetic preferences in large parts of the Central European population and is categorized as 'ugly' [77-79].

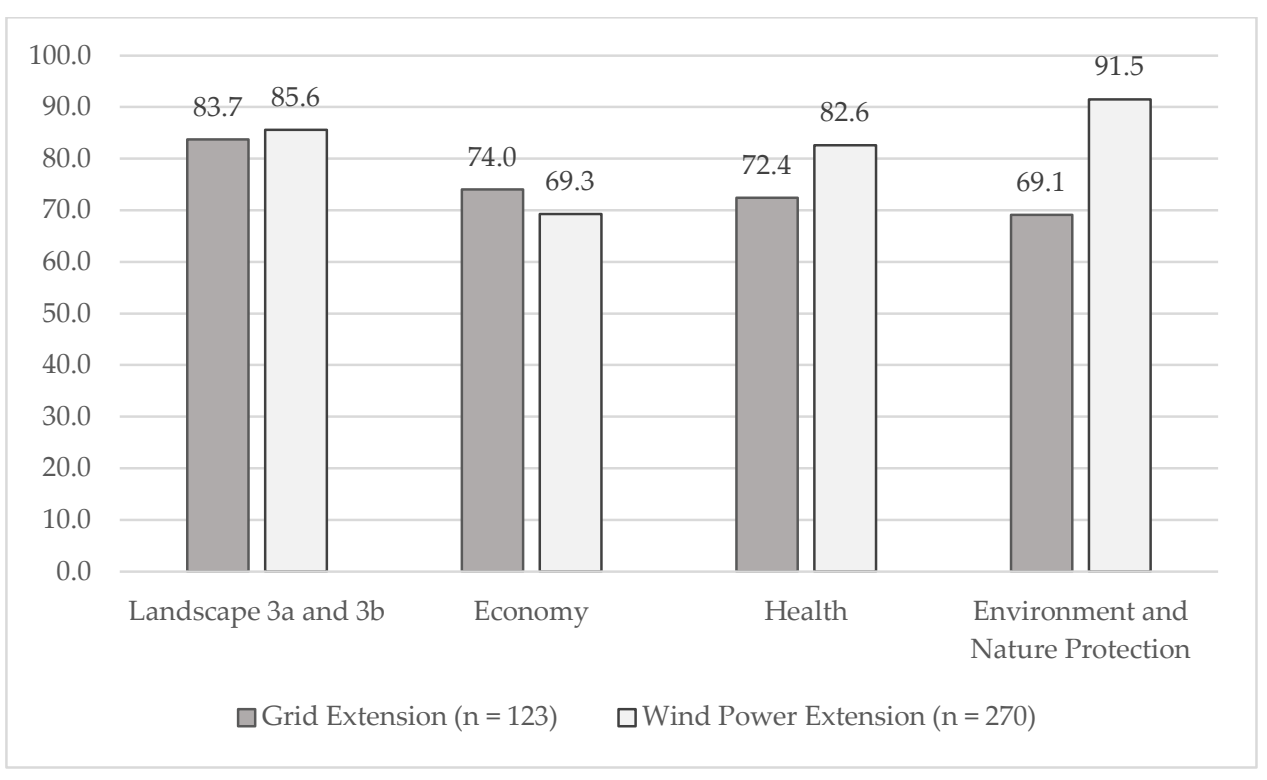

Figure 5. Percentage shares of the arguments of citizens' initiatives against the plants for the generation and transmission of renewable electricity in their websites (homepage or Facebook, own presentation based on: Kühne et al. [65]).

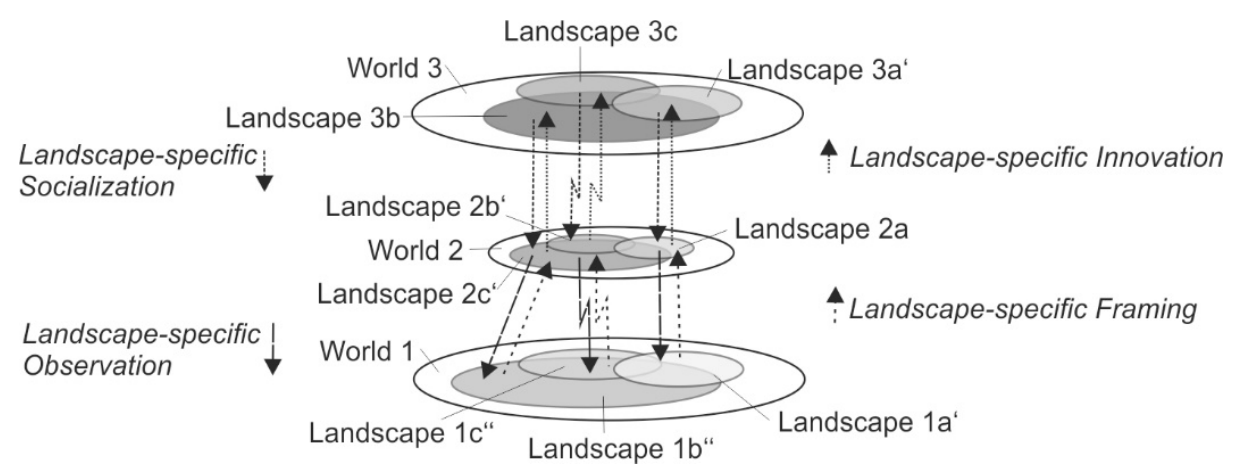

Figure 6. The difference between one's own normative conceptions (Landscape 2a) of the observation of Landscape $\left(1 a^{\prime}\right)$, caused by the change of material objects. This can become a trigger for a social landscape conflict (own illustration).

The example of the physical manifestations of the energy system transformation shows very clearly how changeable the Landscapes $2 a$ and $2 a^{\prime}$ as well as the Landscapes $3 b$ and $3 b^{\prime}$ are [24]. The generation of Landscape 2a is based on the respective current object arrangements of Landscape 1. If wind turbines are part of these object arrangements, they become part of the individual native normal landscape and successively become part of Landscape 3a'. However, Landscapes $3 b$ and $2 b^{\prime}$ are also subject to change, which in turn has a coupling between the aesthetic and moral content of these landscapes: A positive moral connotation means that the facilities of the energy system transformation are framed with the aesthetic evaluation pattern of 'sublimity' or cognitively attributed modernity, significantly more often by younger, non-conservative, and female sections of the population $[24,79]$. The different interpretation and evaluation of the facilities for the production and distribution of renewable energy is not limited to the Landscapes $2 a, 3 a^{\prime}, 3 b$, and $3 b^{\prime}$, but extends to the Landscapes $3 c$, $2 c^{\prime}$, and $3 c^{\prime}$ (Figure 7). For example, the expert advocates the erection of a wind power plant, because 
the location is suitable from his scientific understanding, while the local person rejects the erection as 'destruction of the home'. A common understanding of 'desirable Landscape 1' does not exist, the goals are incompatible, a landscape conflict arises, which in future (not shown) will involve many more people. Additionally, in technical discourses these facilities are considered to be harmful to the landscape' (e.g., [31,71-82]), whereby often an essentialist interpretation of Landscape 1 is used, up to the recognition of the necessity to reinterpret the contents of Landscape $3 \mathrm{~b}$ by new patterns of interpretation and evaluation in Landscape 3c (for example [83,84]; Figure 8). In comparison to the representations of opponents (in Figure 6), there is a very low representation of Landscape $3 a$ and $3 b$, an indicator of the low level of agreement between Landscapes $3 a$ and $3 b$ compared to $3 c$, as shown in Figure 7. In the terminology chosen here, the study was to examine the characteristics of landscape 3c, in contrast to Landscapes 3b and 3a'. The graphic representation of the conflicts thus established is shown in Figures 7 and 9. Even if it becomes clear from this that the number of patterns of interpretation and evaluation as well as the relations between the Landscapes $2 a, 2 b$, and $2 c$ as well as $3 a, 3 b, 3 c$ and derivations is considerable, the resulting conflicts, and these will be the subject of the following, can be discussed with Ralf Dahrendorf [49] in terms of the antagonism between forces of persistence and progression: In other words, the division of groups "who have, so to speak, an interest in the existence of order or a progressive interest in the change of order" [49]. They can show a different degree of intensity and brutality, so that conflict can range from a technical dispute about landscape understanding [85-91] to bloody fights. Landscape conflicts are more likely to reach this level of brutality when they are also intense (in Germany, for example, in the disputes over the Stuttgart 21 railway station project [92,93]), an intensity that conflicts over the physical manifestations of energy system transformation do not usually reach, as they usually remain local and only a comparatively small number of people are affected [94,95]. These conflicts are also subject to the risk that their intensity (and also brutality) will increase if they are not regulated, and there is a tendency to expand geographically (e.g., national associations of local conflict participants).

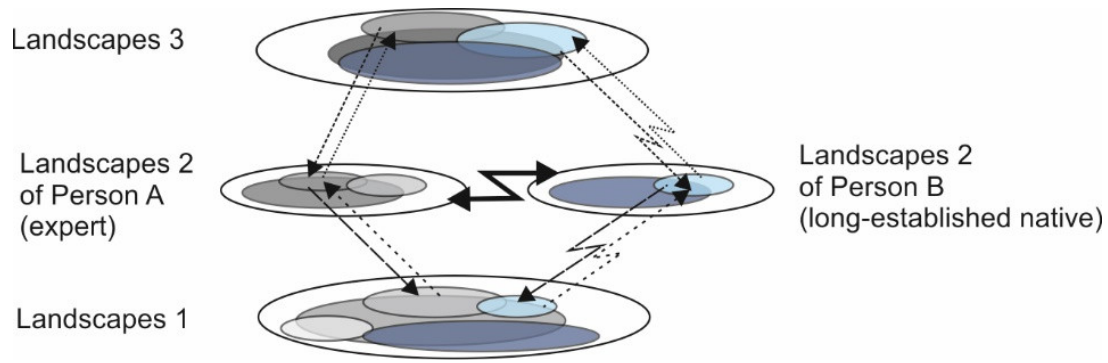

Figure 7. Example of a supra-individual landscape conflict. The interpretations and evaluations of a person (A) with expert special knowledge and a longtime resident (B) contradict each other. (For the sake of clarity, no captions have been added to the graphic, which are based on the previous illustrations. Own illustration).

Landscape conflicts can be dealt with in various ways, but it seems impossible for democratic states to suppress landscape conflicts permanently, on the one hand, because the electoral population can use them as a basis for their electoral decision, and on the other hand, because the participation of different actors in planning projects is legally prescribed. The solution of landscape conflicts is meant to maintain a social status quo; after all, changes of Landscape 1 are based on changes in society. This, however, means a restriction of life chances, since the modernization of society is directed towards maximizing life chances, with the energy system transformation of future generations as well [65,97,98]. A further strategy for dealing with landscape conflicts, which lies beyond the Dahrendorf triad of suppression, solution, and regulation, is the avoidance of landscape conflicts through 'desensitization' $[99,100]$. Here, changes in Landscape 1 are carried out below the 'perception threshold' or are withdrawn from perception by 'camouflage'. In the context of the energy system transformation, these attempts have 
had varying degrees of success: While conflicts can be avoided by underground cabling, the camouflage of wind power plants—because of their dimensionality—is hardly a feasible undertaking. [101-103]. Ultimately, in democratic societies, most landscape conflicts are resolved by efforts to find a solution. A successful settlement of conflicts is-as described in the previous section-not without prerequisites. In the following, current studies on (landscape-related) conflicts over energy system transformation in Germany will be used to examine the preconditions and institutional framework conditions for conflict resolution using Germany as an example (especially [96,104-122]):

- In most cases, landscape conflicts (in this case in the context of the energy system transformation) are not accepted as normal by the parties involved, but are regarded as a state contrary to the norm that runs counter to the desired 'harmony'.

- In the process of negotiation, the parties to the conflict are often rather diffuse in terms of their level of organization, with actors joining in, others withdrawing, and others changing positions. The legitimacy of spokespersons is often called into question by the other conflict party. This has the following consequences: In particular, the interest groups representing citizens (e.g., organized in citizen's initiatives or movements) are struggling for recognition as an organized conflict party. In the struggle for this recognition, they often resort to strongly polarized and moralizing arguments [123].

- Polarizing and moralizing communication is contrary to the rules of fair communication.

- The state, which according to Dahrendorf should have the role of an independent authority to monitor compliance with rules, has itself become a party to the conflict in numerous current expansions of facilities for the production and management of renewable energies. The problem is documented by the fact that on the one hand it is promoting energy system transformation institutionally and financially, and on the other hand is also responsible for its regulation via planning. The legal framework for dealing with landscape conflicts is also ambiguous and can be interpreted in contradictory ways. The Federal Nature Conservation Act, for example, calls for the preservation of the 'beauty' of the landscape, but without clarifying what is meant by either 'beauty' or 'landscape' [124-126].

- The imputation of decisions is made more difficult, or externalized to the judicial system, because of the low degree of organization regarding the conflict parties, the large number of actors from politics, business, planning, citizens (initiatives), and so forth. Thus, a task of an administrative handling of Landscape 1, via the detour of an aesthetic, moral, and political transformation, becomes a question of binding jurisdiction (cf. [127,128]).

With regard to the organizational capability of the parties to the landscape conflict, quite different developments can be found in recent years: Firstly, the ability for self-organization has increased as a result of the expansion of education since the late 1960s $[129,130]$; secondly, the speed of organizing a position is increasing rapidly through the use of new media [131,132]. Thirdly, however, the number of special interests is also increasing (for example, species protection, geotope protection, landscape aesthetics, interests of dog owners, hang-gliders, geocachers, people interested in bathing, walkers, hobby farmers, and many more), which counteracts the formation and organization of conflict interests [65].

A major challenge for the regulation of conflicts over energy system transformation is the frequent lack of agreement on the subject of communication. The communication of 'affected persons' is dominated by references to Landscapes $2 a$ and $3 a^{\prime}$, sometimes Landscapes $3 b$ and $2 b^{\prime}$, while expert communication is carried out at Landscape $3 c$ level. Regarding arguments made with reference to landscape, planning is often directed more towards World 1 and not Landscape 1 . For example, in the 'expert' communication in Internet videos on network expansion, questions concerning technical, planning, and economic aspects dominate [132], while citizens in general and citizens' initiatives in particular are strongly oriented towards the preservation of the current state of Landscape 1; in this case, they tend to show emotional ties or aesthetic affections, and use or imitate Landscape 3c 
communication at best for strategic reasons (since it can be used in court) in order to lend significance to their concern [96,133-136]. Against this background, landscape conflicts (strongly generalized) can be interpreted with the combination of Popper's Three Worlds Theory and Dahrendorf's Conflict Theory-as shown in Figure 9.

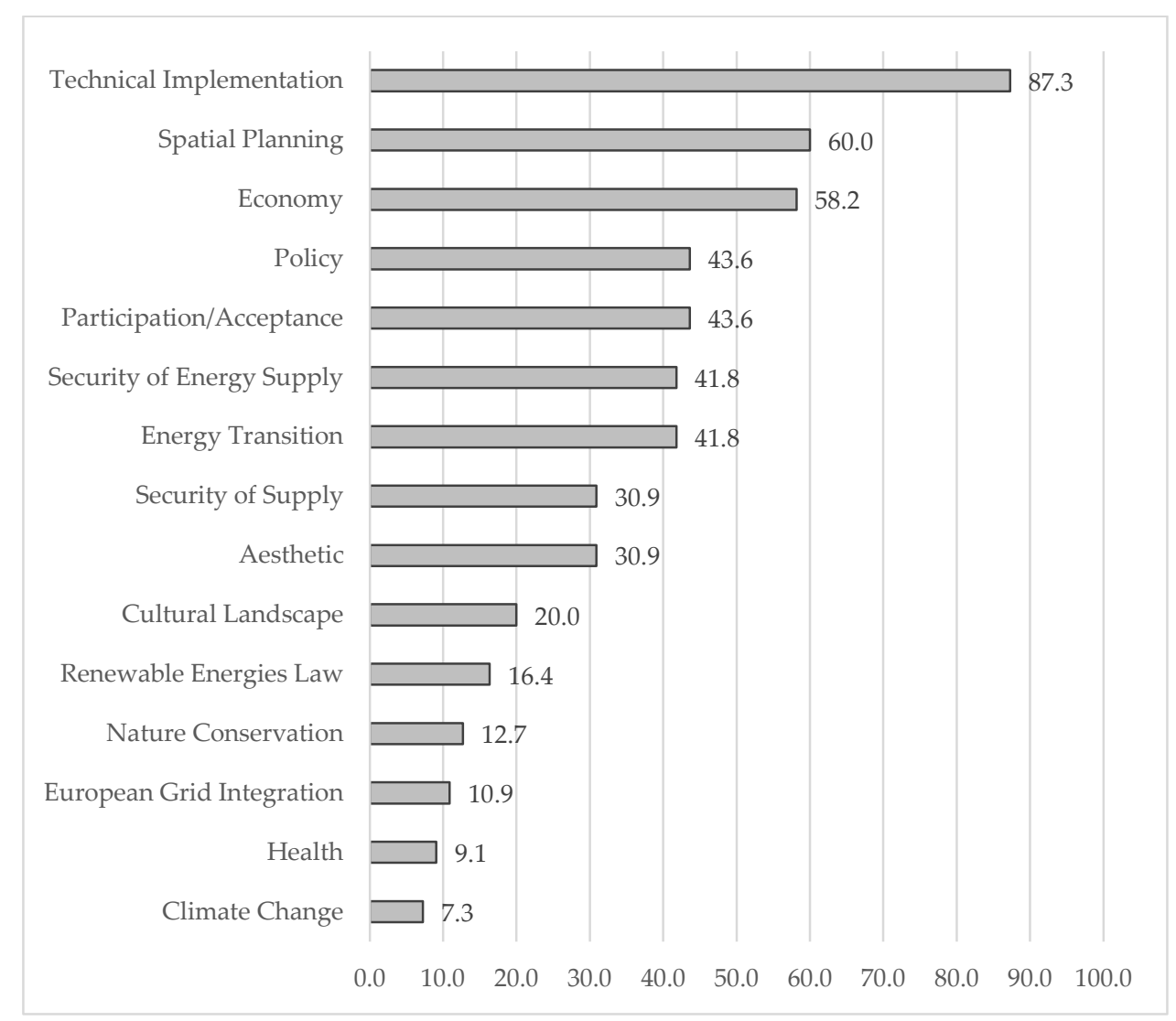

Figure 8. Topics dealt with in the analyzed Internet videos $(n=55)$. The Internet videos were almost exclusively representations of an expert discourse (in relation to Landscape: $3 c$ ); only one of the videos contained the views of people who opposed the physical manifestos of the energy system transformation (own illustration based on Kühne and Weber [96]).

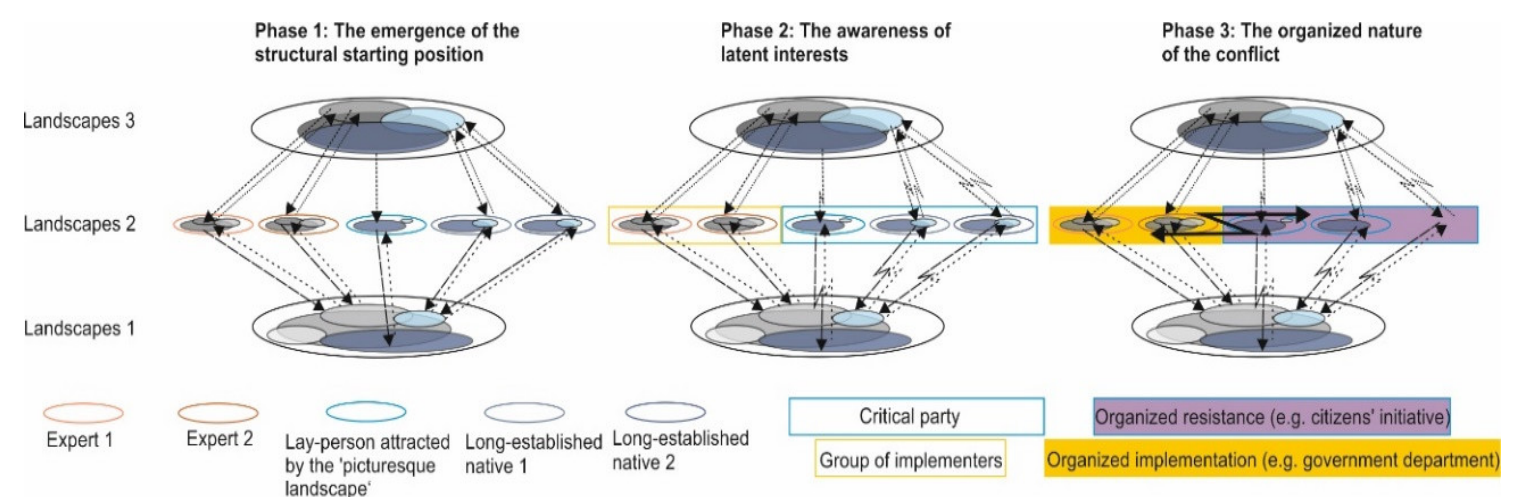

Figure 9. The development of a (local) landscape conflict, in the light of the combination of Popper's Three Worlds Theory and Dahrendorf's Conflict Theory (own illustration).

As a result of the widespread impression that one's own ideas on Landscape $2 a, 3 a^{\prime}, 3 b$, and 2' cannot be heard, either in relation to Landscapes $3 c$ and $2 c^{\prime}$ or in the political-administrative system, the protest against the changes in Landscape 1 is often transformed into an opposition to liberal democracy, 
while populist interpretations of the world are updated [137-139], which in turn is connected with a further (political) polarization of society. This can also be interpreted as an indicator for the high degree of intensity of landscape conflicts around the energy system transformation and illustrates the necessity of its rational regulation [140-143].

The complexity of landscape conflicts in the context of energy system transformation is illustrated by the fact that the conflicts develop differently at local level, while the conflict phases shown in Figure 9 run locally asynchronously. In the first phase, the conflict is structurally designed, in the different interpretation of Landscape 1, from an expert perspective (suffix: c), stereotypical perspective (suffix: b), and home-normal landscape perspective (suffix: a, the suffixes have not been included in the figure for reasons of clarity; they are intended to be similar to Figure 7). In the second phase-for example, in the case of a planned change to landscape 1 through the construction of a wind farm -the quasi-groups of change (here: group of implementers) and persistence (here: critical party) become aware of their latent interests. In the third phase they are organized and have dichotomous identities. Different perspectives on landscape (as in $\mathrm{a}$ and $\mathrm{b}$ ) are abandoned in favor of a dichotomous world view. The conflict parties are strongly institutionalized. However, the degree of institutionalization changes at different levels of scale and between different local contexts, which-beyond the dominance of moral communication-is detrimental to conflict resolution. The connections to supra-local levels are also differentiated. The result is a simultaneity of the different conflict phases, different conflict coalitions, different intensities, and brutalities of conflicts on and between spatial levels (Figure 10). The simultaneity of different conflict phases in the local context and their feedback with the supra-local level illustrates the complexity of the conflict events. The parties to the conflict also exhibit very different degrees of organization, especially those who oppose the physical manifestos of energy system transformation (sometimes against energy system transformation as a whole). This makes rational conflict resolution less likely, as does the intensive involvement of state representatives in the conflicts on and between spatial levels. This diversity of conflicts over energy system transformation makes rational regulation difficult.

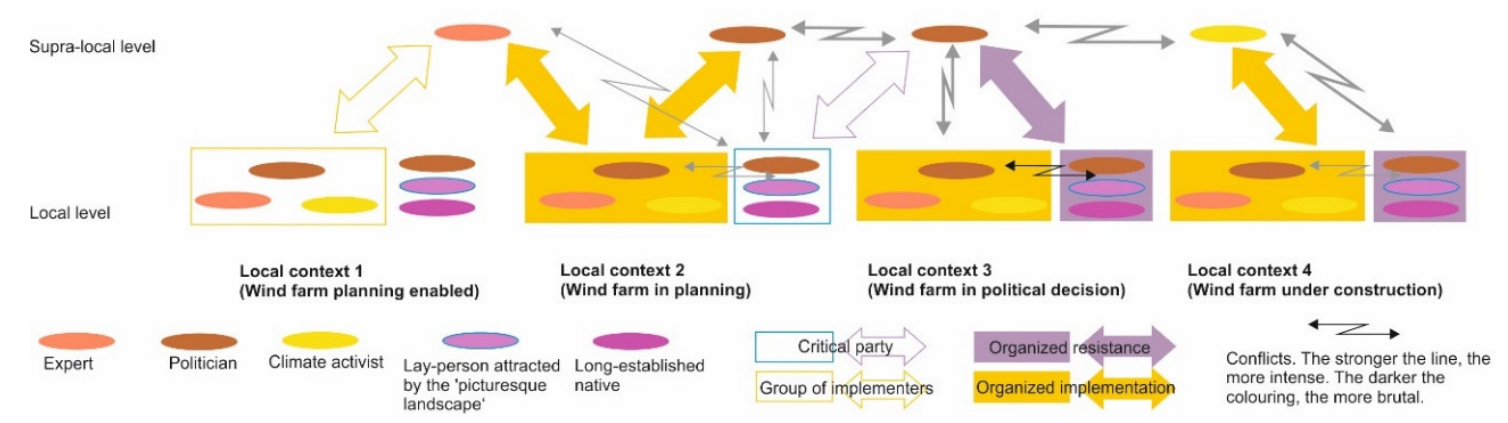

Figure 10. Exemplary presentation of landscape conflicts in the context of the energy system transformation, here on the level of Landscapes 2, subdivided according to different local conflicts and their supra-local connection (own illustration).

Attempts to solve or suppress landscape conflicts are not very appropriate for a democratic and pluralistic society $[144,145]$. The solution of landscape conflicts intends to eliminate their social causes, but these lie in the plural and differentiated society, whose parts congruently have different demands on landscape and its physical foundations while becoming increasingly diverse with regard to landscape interpretations and evaluations. Thus, the solution of landscape conflicts would mean a unification of society. The suppression of landscape conflicts would mean a disregard for landscape needs, interpretations, and evaluations of the citizens, which would be enforced by mechanisms of domination and could ultimately be broken up by eruptive social events alone. In this respect, in a democratically constituted society the way of settling landscape conflicts seems to be the appropriate one (see also [140,141,144-148]). 


\section{Conclusions-Possibilities and Limits of the Theoretical Framing of Landscape and Landscape Conflicts}

The case study of landscape conflicts in relation to the energy system transformation in Germany has demonstrated the analytical potential of the theory of the three landscapes as derived from Karl Popper's Three Worlds Theory. The division into "Landscape 1, Landscape 2a, 2b, and 2c, and Landscape $3 a^{\prime}, 3 b, 3 c$, and $3 c^{\prime \prime \prime}$ allows a clear designation of the level at which landscape is communicated. The connections between the levels can also be addressed, allowing research on the individual levels and relations to be classified. Although only marginally addressed in this essay, this theoretical framework also allows the integration of research from different research paradigms (for example, positivist research on Landscape 1 or social constructivist research on the relation of Landscape 2 and 3). As regards landscape conflicts, this terminology could clearly identify the levels and conflictual relations of landscape. Although the very formal naming facilitates conceptual clarity, it is spontaneously not very catchy as it is not self-explanatory. The terminology of the three landscapes has inherited a limit from Karl Popper's theory of the three worlds: it is strongly related to ideas and not to people, actors, society, and so forth.

This limit can be extended, at least in part, by combining the Three Worlds Theory with Ralf Dahrendorf's conflict theory. However, this extension also seems possible and reasonable for other reasons: Firstly, Dahrendorf not only follows Popper in his work, but operationalizes his considerations in relation to sociological and political as well as political-theoretical questions; secondly, he follows Popper's liberal world view of an 'open society', in the tradition of which his conflict theory and in particular his considerations on conflict regulation can be placed; thirdly, the three worlds can be assigned to individual people as well as social structures, so that conflicts in and between Worlds 2 and 3 as well as in relation to World 1 (here Landscapes 1, 2, and 3) can be made accessible to a social science scientific investigation. Ralf Dahrendorf's conflict theory can be used to frame the phases of landscape conflicts, and the conditions for conflict regulation can also be transferred to landscape conflicts, here using the example of the energy system transformation, thus also creating a framework for assessing conflicts in terms of their intensity and brutality. The conflict analysis according to Dahrendorf is based on the social macro-level, here especially the meso-level. Aspects of the conflicts, such as individual motives for protesting against the physical manifestos of the energy system transformation, remain outside the theoretical framework, such as the individual search for new social capital and meaning in protest, as is frequently observed $[127,148]$.

Following on from Ralf Dahrendorf's comments on conflict theory, it can be assumed that landscape conflicts can also have a productive effect, providing that they are not being suppressed nor is an attempt made to find a solution. The strategy of desensitization can only lead to the goal in a few cases, even a normalization of the facilities for the production and management of regenerative energy in Landscape 2a and 3a' has a more long-term effect. The strategy of a positive moral connection as 'good landscape' also drives the party of the opponents into moralization, here the 'destruction of the homeland' is then cited. In this respect, the effort and regulation of conflicts remains a great challenge. A prerequisite for this is the recognition of landscape conflicts as a normality in a developing society that generates life chances, but also the observance of fair procedures in dealing with conflicts, as well as the recognition of the fundamental legitimacy of the position of the other party. Essential for the success of the energy system transformation without too many unintended side effects is the imputation of responsibilities in the regulation of conflicts and third parties, setting a framework for action, ensuring that it is observed (without getting into conflicts of interest) and, in cases of doubt, making and enforcing decisions, even against the will of the conflict parties.

Funding: This research received no external funding.

Conflicts of Interest: The author declares no conflict of interest. 


\section{References}

1. O'Neill, J.; Walsh, M. Landscape conflicts: Preferences, identities and rights. Landsc. Ecol. 2000, 15, $281-289$. [CrossRef]

2. Buizer, M.; Arts, B.; Westerink, J. Landscape governance as policy integration 'from below': A case of displaced and contained political conflict in the Netherlands. Environ. Plan. C Gov. Policy 2015, 34, 448-462. [CrossRef]

3. Aschenbrand, E.; Michler, T. Linking socio-scientific landscape research with the ecosystem service approach to analyze conflicts about protected area management-The case of the Bavarian Forest National Park. In Modern Approaches to the Visualization of Landscapes; Edler, D., Jenal, C., Kühne, O., Eds.; Springer VS: Wiesbaden, Germany, 2020.

4. Gailing, L.; Bues, A.; Kern, K.; Röhring, A. Socio-spatial dimensions in energy transitions: Applying the TPSN framework to case studies in Germany. Environ. Plan. A Econ. Space 2019, 52, 1112-1130. [CrossRef]

5. Bues, A.; Gailing, L. Energy Transitions and Power: Between Governmentality and Depoliticization. In Conceptualizing Germany's Energy Transition: Institutions, Materiality, Power, Space; Gailing, L., Moss, T., Eds.; Palgrave Macmillan: London, UK, 2016; pp. 69-91.

6. Breukers, S.; Wolsink, M. Wind power implementation in changing institutional landscapes: An international comparison. Energy Policy 2007, 35, 2737-2750. [CrossRef]

7. Wolsink, M. Planning of renewables schemes: Deliberative and fair decision-making on landscape issues instead of reproachful accusations of non-cooperation. Energy Policy 2007, 35, 2692-2704. [CrossRef]

8. Rygg, B.J. Wind power-An assault on local landscapes or an opportunity for modernization? Energy Policy 2012, 48, 167-175. [CrossRef]

9. Mels, T. Globalism, Particularism, and the Greening of Neoliberal Energy Landscapes. In Green Utopianism: Perspectives, Politics and Micro-Practices; Bradley, K., Hedrén, J., Eds.; Routledge: London, UK; New York, NY, USA, 2014; pp. 165-179.

10. Popper, K.R. Objektive Erkenntnis. Ein evolutionärer Entwurf; Hoffmann und Campe: Hamburg, Germany, 1973.

11. Popper, K.R. Auf der Suche nach einer Besseren Welt. Vorträge und Aufsätze aus Dreißig Jahren; Piper: München, Germany, 1984.

12. Dahrendorf, R. Konflikt und Freiheit. Auf dem Weg zur Dienstklassengesellschaft; Piper: München, Germany, 1972.

13. Dahrendorf, R. Der Moderne Soziale Konflikt. Essay zur Politik der Freiheit; Deutsche Verlags-Anstalt: Stuttgart, Germany, 1992.

14. Bruns, A. Die deutsche Energiewende-Beispiel für eine fundamentale Transition. Geogr. Rundsch. 2016, 68, 4-11.

15. Hook, S. 'Energiewende': Von internationalen Klimaabkommen bis hin zum deutschen Erneuerbaren-Energien-Gesetz. In Bausteine der Energiewende; Kühne, O., Weber, F., Eds.; Springer VS: Wiesbaden, Germany, 2018; pp. 21-54.

16. Zoglauer, T. Geist und Gehirn. Das Leib-Seele-Problem in der Aktuellen Diskussion; Vandenhoek: Göttingen, Germany, 1998.

17. Schönwald, A. Ästhetik des Hybriden. In Landschaftsästhetik und Landschaftswandel; Kühne, O., Megerle, H., Weber, F., Eds.; Springer VS: Wiesbaden, Germany, 2017; pp. 161-175.

18. Breckner, I. StadtLandschaften in hybriden Gesellschaftsstrukturen. In StadtLandschaften: Die neue Hybridität von Stadt und Land; Hofmeister, S., Kühne, O., Eds.; Springer VS: Wiesbaden, Germany, 2016; pp. 111-126.

19. Grove, J. Popper 'demystified': The curious ideas of Bloor (and some others) about World 3. Philos. Soc. Sci. 1980, 10, 173-180. [CrossRef]

20. Kühne, O. Landscape Theories. A Brief Introduction; Springer VS: Wiesbaden, Germany, 2019.

21. Greider, T.; Garkovich, L. Landscapes: The Social Construction of Nature and the Environment. Rural Sociol. 1994, 59, 1-24. [CrossRef]

22. Kühne, O. Die Sozialisation von Landschaft. In Handbuch Landschaft; Kühne, O., Weber, F., Berr, K., Jenal, C., Eds.; Springer VS: Wiesbaden, Germany, 2019; pp. 301-312.

23. Nissen, U. Kindheit, Geschlecht und Raum. Sozialisationstheoretische Zusammenhänge Geschlechtsspezifischer Raumaneignung; Beltz Juventa: Weinheim, München, Germany, 1998. 
24. Kühne, O. Die Landschaften 1, 2 und 3 und ihr Wandel: Perspektiven für die Landschaftsforschung in der Geographie—50 Jahre nach Kiel. Ber. Geogr. Landeskd. 2018, 92, 217-231.

25. Dahrendorf, R. Lebenschancen. Anläufe zur Sozialen und Politischen Theorie; Suhrkamp: Frankfurt (Main), Germany, 1979.

26. Kühne, O. Landschaft und Wandel. Zur Veränderlichkeit von Wahrnehmungen; Springer VS: Wiesbaden, Germany, 2018.

27. Drexler, D. Die Wahrnehmung der Landschaft—Ein Blick auf das englische, französische und ungarische Landschaftsverständnis. In Landschaften: Theorie, Praxis und Internationale Bezüge: Impulse zum Landschaftsbegriff mit Seinen Ästhetischen, Ökonomischen, Sozialen und Philosophischen BEZÜGEN mit dem Ziel, die Verbindung von Theorie und Planungspraxis zu Stärken; Bruns, D., Kühne, O., Eds.; Oceano Verlag: Schwerin, Germany, 2013; pp. 37-54.

28. Makhzoumi, J.M. Borrowed or Rooted? The Discourse of 'Landscape' in the Arab Middle East. In Landscape Culture-Culturing Landscapes: The Differentiated Construction of Landscapes; Bruns, D., Kühne, O., Schönwald, A., Theile, S., Eds.; Springer VS: Wiesbaden, Germany, 2015; pp. 111-126.

29. Olwig, K.R. Landscape, Nature, and the Body Politic. From Britain's Renaissance to America's New World; University of Wisconsin Press: Madison, UI, USA, 2002.

30. Kühne, O.; Jenal, C. The threefold landscape change-Basic considerations, conflicts and potentials of virtual landscape research. In Modern Approaches to the Visualization of Landscapes; Edler, D., Jenal, C., Kühne, O., Eds.; Springer VS: Wiesbaden, Germany, 2020.

31. Kühne, O. Landschaft in der Postmoderne. Das Beispiel des Saarlandes; DUV: Wiesbaden, Germany, 2006.

32. Weber, F.; Kühne, O.; Jenal, C.; Aschenbrand, E.; Artuković, A. Sand im Getriebe. Aushandlungsprozesse um die Gewinnung Mineralischer Rohstoffe aus Konflikttheoretischer Perspektive nach Ralf Dahrendorf; Springer VS: Wiesbaden, Germany, 2018.

33. Kühne, O.; Weber, F.; Jenal, C. Der Stromnetzausbau in Deutschland: Formen und Argumente des Widerstands. Geogr. aktuell Sch. 2016, 38, 4-14.

34. Edler, D.; Kühne, O.; Jenal, C.; Vetter, M.; Dickmann, F. Potenziale der Raumvisualisierung in Virtual Reality (VR) für die sozialkonstruktivistische Landschaftsforschung. Kartogr. Nachr. 2018, 68, 245-254. [CrossRef]

35. Kühne, O. Landschaftstheorie und Landschaftspraxis. Eine Einführung aus Sozialkonstruktivistischer Perspektive, 2nd ed.; Aktualisierte und Überarbeitete Auflage; Springer VS: Wiesbaden, Germany, 2018.

36. Proshansky, H.M.; Fabian, A.K.; Kaminoff, R. Place-identity: Physical world socialization of the self. J. Environ. Psychol. 1983, 3, 57-83. [CrossRef]

37. Stotten, R. Kulturlandschaft gemeinsam verstehen-Praktische Beispiele der Landschaftssozialisation aus dem Schweizer Alpenraum. Geogr. Helv. 2013, 68, 117-127. [CrossRef]

38. Kühne, O. Die Sozialisation von Landschaft-Sozialkonstruktivistische Überlegungen, empirische Befunde und Konsequenzen für den Umgang mit dem Thema Landschaft in Geographie und räumlicher Planung. Geogr. Z. 2008, 96, 189-206.

39. Popper, K.R. The Open Society and Its Enemies; Routledge: Abingdon, UK, 2011.

40. Parsons, T. The Social System; Free Press: Glencoe, Scotland, 1951.

41. Marx, K. Das Kapital. Band I. Available online: http://www.mlwerke.de/me/me23/me23_000.htm (accessed on 24 May 2018).

42. Dahrendorf, R. Pfade aus Utopia. Arbeiten zur Theorie und Methode der Soziologie; Piper: München, Germany, 1968.

43. Dahrendorf, R. Die Chancen der Krise. Über die Zukunft des Liberalismus; Deutsche Verlags-Anstalt: Stuttgart, Germany, 1983.

44. Popper, K.R. The Logic Of Scientific Discovery; Routledge: Abingdon, New York, NY, USA, 2002.

45. Dahrendorf, R. Die Krisen der Demokratie. Ein Gespräch mit Antonio Polito; C.H. Beck: München, Germany, 2003.

46. Bonacker, T. Konflikttheorien. Eine Sozialwissenschaftliche Einführung mit Quellen; Leske + Budrich: Opladen, Germany, 1996.

47. Luhmann, N. Systemtheorie der Gesellschaft; Suhrkamp: Berlin, Germany, 2017.

48. Kühne, O.; Leonardi, L. Ralf Dahrendorf. between Social Theory and Political Practice; Palgrave Macmillan: London, UK, 2020. 
49. Dahrendorf, R. Soziale Klassen und Klassenkonflikt in der Industriellen Gesellschaft; Enke: Stuttgart, Germany, 1957.

50. Dahrendorf, R. Liberalism. In The New Palgrave Dictionary of Economics; Eatwell, J., Ed.; Macmillan: London, UK, 1991; pp. 385-389.

51. Dahrendorf, R. Aktive und passive Öffentlichkeit: Über Teilnahme und Initiative im politischen Prozeß moderner Gesellschaften. In Das Publikum; Löffler, M., Ed.; C.H. Beck: München, Germany, 1969; pp. 1-12.

52. Dahrendorf, R. Zu einer Theorie des sozialen Konflikts [1958 erstveröffentlicht]. In Theorien des Sozialen Wandels; Zapf, W., Ed.; Kiepenheuer \& Witsch: Köln, Germany, 1969; pp. 108-123.

53. Moss, T.; Gailing, L. Introduction. In Conceptualizing Germany's Energy Transition: Institutions, Materiality, Power, Space; Gailing, L., Moss, T., Eds.; Palgrave Macmillan: London, UK, 2016; pp. 1-9.

54. Leonardi, L. Introduzione a Dahrendorf; Editori Laterza: Roma, Italy; Bari, Italy, 2014.

55. Kühne, O. Zur Aktualität von Ralf Dahrendorf. Einführung in sein Werk; Springer VS: Wiesbaden, Germany, 2017.

56. Gratzel, G.A. Freiheit, Konflikt und Wandel: Bemerkungen zum Liberalismus-Verständnis bei Ralf Dahrendorf. In Jahrbuch zur Liberalismus-Forschung, 2nd ed.; Fleck, H.-G., Frölich, J., Padtberg, B.-C., Eds.; Nomos: Baden-Baden, Germany, 1990; pp. 11-45.

57. Pasqualetti, M.J. Wind energy landscapes: Society and technology in the California desert. Soc. Nat. Resour. Int. J. 2001, 14, 689-699. [CrossRef]

58. Öko-Institut e.V. Energie-Wende. Wachstum und Wohlstand ohne Erdöl und Uran; Dreisam Verlag: Freiburg, Germany, 1980.

59. Hook, S. Einführung in die Regenerative Energiewirtschaft; Springer VS: Wiesbaden, Germany, 2019.

60. Gullberg, A.T.; Ohlhorst, D.; Schreurs, M. Towards a low carbon energy future-Renewable energy cooperation between Germany and Norway. Renew. Energy 2014, 68, 216-222. [CrossRef]

61. Gochermann, J. Expedition Energiewende; Springer Spektrum: Wiesbaden, Germany, 2016.

62. Kloepfer, M.; Bruch, D. Die Laufzeitverlängerung im Atomrecht zwischen Gesetz und Vertrag. JuristenZeitung 2011, 66, 377-387. [CrossRef]

63. BMWi. Erneuerbare Energien in Zahlen: Nationale und Internationale Entwicklung im Jahr 2015. Available online: https://www.bmwi.de/BMWi/Redaktion/PDF/E/erneuerbare-energien-in-zahlen, property= pdf, bereich=bmwi2012, sprache=de,rwb=true.pdf (accessed on 13 January 2017).

64. Bundesministerium für Wirtschaft und Energie. Bruttostromerzeugung in Deutschland. Available online: https://www.bmwi.de/Redaktion/DE/Infografiken/Energie/Energiedaten/Energietraeger/ energiedaten-energietraeger-27.html (accessed on 16 June 2020).

65. Kühne, O.; Weber, F.; Berr, K. The productive potential and limits of landscape conflicts in light of Ralf Dahrendorf's conflict theory. Soc. Mutam. Politica 2019, 10, 77-90.

66. Klagge, B. Governance-Prozesse für erneuerbare Energien-Akteure, Koordinations- und Steuerungsstrukturen. In Governance-Prozesse für Erneuerbare Energien; Klagge, B., Arbach, C., Eds.; Selbstverlag: Hannover, Germany, 2013; pp. 7-16.

67. Plankl, R. Regionale Verteilungswirkungen durch das Vergütungs- und Umlagesystem des Erneuerbare-Energien-Gesetzes (EEG). Available online: http://literatur.ti.bund.de/digbib_extern/dn052693. pdf (accessed on 16 July 2017).

68. Neukirch, M. Konflikte um den Ausbau der Stromnetze: Status und Entwicklung Heterogener Protestkonstellationen. SOI Discussion Paper 2014-01. Available online: https://www.sowi.uni-stuttgart.de/ dokumente/forschung/soi/soi_2014_1_Neukirch_Konflikte_um_den_Ausbau_der_Stromnetze.pdf (accessed on 11 September 2019).

69. Neukirch, M. Protests against German electricity grid extension as a new social movement? A journey into the areas of conflict. Energy Sustain. Soc. 2016, 6, 1-15. [CrossRef]

70. Riegel, C.; Brandt, T. Eile mit Weile-Aktuelle Entwicklungen beim Netzausbau. Nachr. ARL 2015, 45, 10-16.

71. Bundesnetzagentur. Bundesbedarfsplan (2015). Available online: https://www.netzausbau.de/ bedarfsermittlung/2024/bundesbedarfsplan/de.html (accessed on 24 May 2017).

72. Ipsen, D. Ort und Landschaft; VS Verlag für Sozialwissenschaften: Wiesbaden, Germany, 2006.

73. Beck, U. Risikogesellschaft. Auf dem Weg in Eine Andere Moderne; Suhrkamp: Frankfurt (Main), Germany, 1986.

74. Schulze, G. Die Erlebnisgesellschaft. Kultursoziologie der Gegenwart; Campus-Verlag: Frankfurt (Main), Germany; New York, NY, USA, 1993. 
75. Berr, K.; Kühne, O. Moral und Ethik von Landschaft. In Handbuch Landschaft; Kühne, O., Weber, F., Berr, K., Jenal, C., Eds.; Springer VS: Wiesbaden, Germany, 2019; pp. 351-365.

76. Kirchhoff, T.; Trepl, L. Landschaft, Wildnis, Ökosystem: Zur kulturbedingten Vieldeutigkeit ästhetischer, moralischer und theoretischer Naturauffassungen: Einleitender Überblick. In Vieldeutige Natur: Landschaft, Wildnis und Ökosystem als Kulturgeschichtliche Phänomene; Kirchhoff, T., Trepl, L., Eds.; Transcript Verlag: Bielefeld, Germany, 2009; pp. 13-68.

77. Linke, S.I. Die Ästhetik medialer Landschaftskonstrukte. Theoretische Reflexionen und Empirische Befunde; Springer VS: Wiesbaden, Germany, 2019.

78. Linke, S. Ästhetik, Werte und Landschaft-Eine Betrachtung zwischen philosophischen Grundlagen und aktueller Praxis der Landschaftsforschung. In Landschaftsästhetik und Landschaftswandel; Kühne, O., Megerle, H., Weber, F., Eds.; Springer VS: Wiesbaden, Germany, 2017; pp. $23-40$.

79. Berr, K.; Kühne, O. "Und das Ungeheure Bild der Landschaft ... ". The Genesis of Landscape Understanding in the German-Speaking Regions; Springer VS: Wiesbaden, Germany, 2020.

80. Nohl, W. Windkraftwerke sind keine Windmühlen: Warum moderne »Energie-Landschaften« nicht schön sind. In Geopferte Landschaften: Wie die Energiewende Unsere Umwelt Zerstört; Etscheit, G., Ed.; Heyne: München, Germany, 2016; pp. 114-136.

81. Nohl, W. Landschaftsästhetik Heute. Auf dem Wege zu Einer Landschaftsästhetik des Guten Lebens; Ausgewählte Aufsätze aus Vier Jahrzehnten; Oekom-Verlag: München, Germany, 2015.

82. Fassl, P. Photovoltaik—Windkraft-Biogasanlagen. Zur Frage einer kulturlandwirtschaftlichen Bewertung. In Energielandschaften Gestalten: Leitlinien und Beispiele für Bürgerpartizipation; Bund Heimat und Umwelt in Deutschland, Ed.; Selbstverlag: Bonn, Germany, 2014; pp. 59-81.

83. Linke, S. Ästhetik der neuen Energielandschaften-Oder: "Was Schönheit ist, das weiß ich nicht". In Bausteine der Energiewende; Kühne, O., Weber, F., Eds.; Springer VS: Wiesbaden, Germany, 2018; pp. 409-429.

84. Selman, P. Learning to Love the Landscapes of Carbon-Neutrality. Landsc. Res. 2010, 35, 157-171. [CrossRef]

85. Schenk, W. Landschaft als zweifache sekundäre Bildung-Historische Aspekte im aktuellen Gebrauch von Landschaft im deutschsprachigen Raum, namentlich in der Geographie. In Landschaften: Theorie, Praxis und Internationale Bezüge: Impulse zum Landschaftsbegriff mit Seinen Ästhetischen, Ökonomischen, Sozialen und Philosophischen Bezügen mit dem Ziel, die Verbindung von Theorie und Planungspraxis zu Stärken; Bruns, D., Kühne, O., Eds.; Oceano Verlag: Schwerin, Germany, 2013; pp. 23-36.

86. Berr, K.; Schenk, W. Begriffsgeschichte. In Handbuch Landschaft; Kühne, O., Weber, F., Berr, K., Jenal, C., Eds.; Springer VS: Wiesbaden, Germany, 2019; pp. 23-38.

87. Hard, G. Zu Begriff und Geschichte von "Natur" und "Landschaft" in der Geographie des 19. und 20. Jahrhunderts [1983 erstveröffentlicht]. In Landschaft und Raum: Aufsätze zur Theorie der Geographie; Hard, G., Ed.; Universitätsverlag Rasch: Osnabrück, Germany, 2002; pp. 171-210.

88. Müller, G. Zur Geschichte des Wortes Landschaft. In "Landschaft" als Interdisziplinäres Forschungsproblem: Vorträge und Diskussionen des Kolloquiums am 7./8. November 1975 in Münster; Hartlieb von Wallthor, A., Quirin, H., Eds.; Aschendorff: Münster, Germany, 1977; pp. 3-13.

89. Hokema, D. Landschaft im Wandel? Zeitgenössische Landschaftsbegriffe in Wissenschaft, Planung und Alltag; Springer VS: Wiesbaden, Germany, 2013.

90. Vicenzotti, V. Der» Zwischenstadt «-Diskurs. Eine Analyse Zwischen Wildnis, Kulturlandschaft und Stadt; Transcript Verlag: Bielefeld, Germany, 2011; ISBN 978-3-8376-1829-7.

91. Wojtkiewicz, W. Sinn-Bild_Landschaft. Landschaftsverständnisse in der Landschaftsplanung: Eine Untersuchung von Idealvorstellungen und Bedeutungszuweisungen; Technische Universität Berlin: Berlin, Germany, 2015.

92. Krüger, S. Stuttgart 21-Interessen, Hintergründe, Widersprüche. Inf. Raumentwickl. 2012, 589-603.

93. Thaa, W. "Stuttgart 21"-Krise oder Repolitisierung der repräsentativen Demokratie? Politische Vierteljahresschr. 2013, 54, 1-20. [CrossRef]

94. Weber, F. Konflikte um die Energiewende. Vom Diskurs zur Praxis; Springer VS: Wiesbaden, Germany, 2018.

95. Weber, F.; Jenal, C. Gegen den Wind-Konfliktlinien beim Ausbau erneuerbarer Energien in Großschutzgebieten am Beispiel der Windenergie in den Naturparken Soonwald-Nahe und Rhein-Westerwald. In Wohin des Weges? Regionalentwicklung in Großschutzgebieten; Weber, F., Weber, F., Jenal, C., Eds.; Selbstverlag: Hannover, Germany, 2018; pp. 217-249. 
96. Kühne, O.; Weber, F. Der Energienetzausbau in Internetvideos-Eine quantitativ ausgerichtete diskurstheoretisch orientierte Analyse. In Landschaftswandel-Wandel von Machtstrukturen; Kost, S., Schönwald, A., Eds.; Springer VS: Wiesbaden, Germany, 2015; pp. 113-126.

97. Tremmel, J. Eine Theorie der Generationengerechtigkeit; Mentis Verlag GmbH: Münster, Germany, 2012.

98. Berr, K. Ethische Aspekte der Energiewende. In Bausteine der Energiewende; Kühne, O., Weber, F., Eds.; Springer VS: Wiesbaden, Germany, 2018; pp. 57-74. ISBN 978-3-658-19508-3.

99. Kühne, O. Stadt_Landschaft_-Hybridität. Ästhetische Bezüge im Postmodernen Los Angeles mit Seinen Modernen Persistenzen; Springer VS: Wiesbaden, Germany, 2012.

100. Kühne, O. Landschaftsästhetik und regenerative Energien-Grundüberlegungen zu De- und Re-Sensualisierungen und inversen Landschaften. In Neue Energielandschaften-Neue Perspektiven der Landschaftsforschung; Gailing, L., Leibenath, M., Eds.; Springer VS: Wiesbaden, Germany, 2013; pp. 101-120.

101. Sontheim, T.; Weber, F. Erdverkabelung und Partizipation als mögliche Lösungswege zur weiteren Ausgestaltung des Stromnetzausbaus? Eine Analyse anhand zweier Fallstudien. In Bausteine der Energiewende; Kühne, O., Weber, F., Eds.; Springer VS: Wiesbaden, Germany, 2018; pp. 609-630.

102. Cowell, R. Wind power, landscape and strategic, spatial planning-The construction of 'acceptable locations' in Wales. Land Use Policy 2010, 27, 222-232. [CrossRef]

103. Schöbel, S. Windenergie und Landschaftsästhetik. Zur landschaftsgerechten Anordnung von Windfarmen; Jovis Verlag: Berlin, Germany, 2012.

104. Becker, S.; Klagge, B. Context Shaping und Transitionen zur Nachhaltigkeit: Das Beispiel Energiewende. Ber. Geogr. Landeskd. 2017, 91, 155-171.

105. Bräuer, M. Energiewende und Bürgerproteste. Eine Untersuchung der Kommunikation von Bürgerinitiativen im Themenfeld Netzausbau; Universitätsverlag Ilmenau: Ilmenau, Germany, 2017.

106. Schmidt, C.; Hage, G.; Hoppenstedt, A.; Bruns, D.; Kühne, O.; Schuster, L.; Münderlein, D.; Bernstein, F.; Weber, F.; Roßmeier, A.; et al. Landschaftsbild \& Energiewende. Band 2: Handlungsempfehlungen; Bundesamt für Naturschutz: Bonn-Bad Godesberg, Germany, 2018.

107. Schmitt, T. Die Debatten um neue Stromtrassen als Symptomkonflikte der Energiewende. Geogr. Rundsch. 2016, 68, 18-25.

108. Weber, F.; Jenal, C.; Roßmeier, A.; Kühne, O. Conflicts around Germany's Energiewende: Discourse patterns of citizens' initiatives. Quaest. Geogr. 2017, 36, 117-130. [CrossRef]

109. Leibenath, M.; Otto, A. Competing Wind Energy Discourses, Contested Landscapes. Landsc. Online 2014, 38 , 1-18. [CrossRef]

110. Gailing, L. Die räumliche Governance der Energiewende: Eine Systematisierung der relevanten Governance-Formen. In Bausteine der Energiewende; Kühne, O., Weber, F., Eds.; Springer VS: Wiesbaden, Germany, 2018; pp. 75-90.

111. Gailing, L. Die Landschaften der Energiewende-Themen und Konsequenzen für die sozialwissenschaftliche Landschaftsforschung. In Neue Energielandschaften-Neue Perspektiven der Landschaftsforschung; Gailing, L., Leibenath, M., Eds.; Springer VS: Wiesbaden, Germany, 2013; pp. 207-215.

112. Hoeft, C.; Messinger-Zimmer, S.; Zilles, J. Bürgerproteste in Zeiten der Energiewende: Ein Fazit in neun Thesen. In Bürgerproteste in Zeiten der Energiewende: Lokale Konflikte um Windkraft, Stromtrassen und Fracking; Hoeft, C., Messinger-Zimmer, S., Zilles, J., Eds.; Transcript Verlag: Bielefeld, Germany, 2017; pp. 235-254.

113. Kamlage, J.-H.; Warode, J.; Reinermann, J.; Vries, N.d.; Trost, E. Von Konflikt und Dialog: Manifestationen der Energiewende in den Transformationsfeldern Netzausbau, Biogas und Windkraft. In Landschaft als Prozess; Duttmann, R., Kühne, O., Weber, F., Eds.; Springer VS: Wiesbaden, Germany, 2020.

114. Kühne, O. 'Neue Landschaftskonflikte'-Überlegungen zu den physischen Manifestationen der Energiewende auf der Grundlage der Konflikttheorie Ralf Dahrendorfs. In Bausteine der Energiewende; Kühne, O., Weber, F., Eds.; Springer VS: Wiesbaden, Germany, 2018; pp. 163-186.

115. Kühne, O.; Weber, F. Zur sozialen Akzeptanz der Energiewende. UmweltWirtschaftsForum 2016, 24, $207-213$. [CrossRef]

116. Leibenath, M. Energiewende und Landschafts-Governance: Empirische Befunde und theoretische Perspektiven. In Neue Energielandschaften-Neue Perspektiven der Landschaftsforschung; Gailing, L., Leibenath, M., Eds.; Springer VS: Wiesbaden, Germany, 2013; pp. 45-63.

117. Messinger-Zimmer, S.; Zilles, J. (De-)zentrale Energiewende und soziale Konflikte: Regionale Konflikte um die Vertretung des Gemeinwohls. Vierteljahrsh. Wirtsch. 2016, 85, 41-51. [CrossRef] 
118. Otto, A. Die Diskursforschung in der deutschen Energiewende: Perspektiven und Potenziale. Ber. Geogr. Landeskd. 2017, 91, 117-137.

119. Roesler, T. Akteure der Energiewende: Kommunale Windenergie in Hessen. Geogr. Landeskd. 2014, 88, 399-412.

120. Schmidt, C.; Hage, G.; Hoppenstedt, A.; Bruns, D.; Kühne, O.; Schuster, L.; Münderlein, D.; Bernstein, F.; Weber, F.; Roßmeier, A.; et al. Landschaftsbild \& Energiewende. Band 1: Grundlagen; Bundesamt für Naturschutz: Bonn-Bad Godesberg, Germany, 2018.

121. Hildebrand, J.; Rau, I. Die Akzeptanz des Netzausbaus: Ergebnisse einer umweltpsychologischen Studie. EMF Spektrum 2012, 67, 4-7.

122. Schweiger, S.; Kamlage, J.-H.; Engler, S. Ästhetik und Akzeptanz: Welche Geschichten könnten Energielandschaften erzählen? In Bausteine der Energiewende; Kühne, O., Weber, F., Eds.; Springer VS: Wiesbaden, Germany, 2018; pp. 431-445.

123. Radtke, J. A closer look inside collaborative action: Civic engagement and participation in community energy initiatives. People Place Policy 2014, 8, 235-248. [CrossRef]

124. Atmanagara, J. Chancen und Grenzen der Europäischen Landschaftskonvention zur Steuerung von Prozessen des Landschaftswandels. In Transformation und Landschaft: Die Folgen Sozialer Wandlungsprozesse auf Landschaft; Kühne, O., Gawroński, K., Hernik, J., Eds.; Springer VS: Wiesbaden, Germany, 2015; pp. 307-319.

125. Bruns, D. Die Europäische Landschaftskonvention: Bedarf es eines deutschen Sonderwegs? Stadt + Grün 2006, 14-19. [CrossRef]

126. Bruns, D. Die Euopäische Landschaftskonvention-Eine Antwort auf die landschaftlichen Herausforderungen sich transformierender Gesellschaft. In Transformation und Landschaft: Die Folgen Sozialer Wandlungsprozesse auf Landschaft; Kühne, O., Gawroński, K., Hernik, J., Eds.; Springer VS: Wiesbaden, Germany, 2015; pp. 293-305. ISBN 978-3-658-00604-4.

127. Walter, F.; Marg, S.; Geiges, L.; Butzlaff, F. (Eds.) Die Neue Macht der Bürger. Was Motiviert die Protestbewegungen? BP-Gesellschaftsstudie; Rowohlt: Reinbek bei Hamburg, Germany, 2013.

128. Dahrendorf, R. Bildung ist Bürgerrecht. Plädoyer für eine Aktive Bildungspolitik, Neuauflage; Christian Wegner: Hamburg, 1968.

129. Müller, W. Erwartete und unerwartete Folgen der Bildungsexpansion. In Die Diagnosefähigkeit der Soziologie; Friedrichs, J., Lepsius, M.R., Mayer, K.U., Eds.; Westdeutscher Verlag: Opladen, Germany, 1998; pp. 81-112.

130. Hoffmann-Lange, U. Bildungsexpansion, politisches Interesse und politisches Engagement in den alten Bundesländern. In Demokratie und Partizipation: Festschrift für Max Kaase; Niedermayer, O., Westle, B., Eds.; Westdeutscher Verlag: Wiesbaden, Germany, 2000; pp. 46-64.

131. Münker, S. Emergenz Digitaler Öffentlichkeiten. Die Sozialen Medien im Web 2.0; Suhrkamp: Frankfurt (Main), Germany, 2009.

132. Schmidt, J.-H. Das neue Netz. Merkmale, Praktiken und Folgen des Web 2.0; UVK Verlagsgesellschaft: Konstanz, Germany, 2011.

133. Burckhardt, L. Wer Plant die Planung? Architektur, Politik und Mensch; Martin Schmitz Verlag: Berlin, Germany, 2004.

134. Jenal, C. Ikonologie des Protests-Der Stromnetzausbau im Darstellungsmodus seiner Kritiker(innen). In Bausteine der Energiewende; Kühne, O., Weber, F., Eds.; Springer VS: Wiesbaden, Germany, 2018; pp. 469-487.

135. Kühne, O.; Weber, F. Landschaft und Heimat-argumentative Verknüpfungen durch Bürgerinitiativen im Kontext des Stromnetz- und des Windkraftausbaus. In Heimat: Ein Vielfältiges Konstrukt; Hülz, M., Kühne, O., Weber, F., Eds.; Springer VS: Wiesbaden, Germany, 2019; pp. 163-178.

136. Weber, F. Widerstände im Zuge des Stromnetzausbaus-Eine diskurstheoretische Analyse der Argumentationsmuster von Bürgerinitiativen in Anschluss an Laclau und Mouffe. Ber. Geogr. Landeskd. 2017, 91, 139-154.

137. Reusswig, F. Heimat und politische Parteien. In Heimat: Ein Vielfältiges Konstrukt; Hülz, M., Kühne, O., Weber, F., Eds.; Springer VS: Wiesbaden, Germany, 2019; pp. 371-389.

138. Reusswig, F.; Braun, F.; Heger, I.; Ludewig, T.; Eichenauer, E.; Lass, W. Against the wind: Local opposition to the German Energiewende. Util. Policy 2016, 41, 214-227. [CrossRef]

139. Eichenauer, E.; Reusswig, F.; Meyer-Ohlendorf, L.; Lass, W. Bürgerinitiativen gegen Windkraftanlagen und der Aufschwung rechtspopulistischer Bewegungen. In Bausteine der Energiewende; Kühne, O., Weber, F., Eds.; Springer VS: Wiesbaden, Germany, 2018; pp. 633-651. 
140. Kamlage, J.-H.; Nanz, P.; Richter, I. Ein Grenzgang-Informelle, dialogorientierte Bürgerbeteiligung im Netzausbau der Energiewende. In Kursbuch Bürgerbeteiligung, 2nd ed.; Sommer, J., Ed.; Verlag der Deutschen Umweltstiftung: Berlin, Germany, 2017; pp. 56-77.

141. Kamlage, J.-H.; Nanz, P.; Fleischer, B. Dialogorientierte Bürgerbeteiligung im Netzausbau. In Im Brennpunkt: Die Energiewende als Gesellschaftlicher Transformationsprozess; Rogall, H., Binswanger, H.-C., Ekardt, F., Grothe, A., Hasenclever, W.-D., Hauchler, I., Jänicke, M., Kollmann, K., Michaelis, N.V., Nutzinger, H.G., et al., Eds.; Metropolis-Verlag: Marburg, Germany, 2014; pp. 195-216.

142. Langer, K. Frühzeitige Planungskommunikation-Ein Schlüssel zur Konfliktbewältigung bei der Energiewende? In Bausteine der Energiewende; Kühne, O., Weber, F., Eds.; Springer VS: Wiesbaden, Germany, 2018; pp. 539-556.

143. Weber, F.; Kühne, O.; Jenal, C.; Sanio, T.; Langer, K.; Igel, M. Analyse des Öffentlichen Diskurses zu Gesundheitlichen Auswirkungen von Hochspannungsleitungen-Handlungsempfehlungen für die Strahlenschutzbezogene Kommunikation beim Stromnetzausbau: Ressortforschungsbericht. Available online: https://doris.bfs.de/jspui/bitstream/urn:nbn:de:0221-2016050414038/3/BfS_2016_3614S80008.pdf (accessed on 17 October 2018).

144. Benighaus, C.; Wachinger, G.; Renn, O. Bürgerbeteiligung. Konzepte und Lösungswege für die Praxis; Wolfgang Metzner Verlag: Frankfurt (Main), Germany, 2016.

145. Koop, A.; Renkamp, A.; Märker, O. Von der Einwandsbehandlung zur konstruktiven Beteiligung? Über die mögliche Zukunft der Bürgerbeteiligung in Deutschland. Nat. Landsch. 2014, 89, 234-239.

146. Neunecker, M. Partizipation Trifft Repräsentation. Die Wirkungen Konsultativer Bürgerbeteiligung auf Politische Entscheidungen; Springer VS: Wiesbaden, Germany, 2016; ISBN 9783658130701.

147. Hülz, M.; Kühne, O. Handlungsbedarfe und -empfehlungen an die räumliche Planung vor dem Hintergrund einer zunehmenden Internationalisierung der Gesellschaft. In Internationalisierung der Gesellschaft und die Auswirkungen auf die Raumentwicklung: Beispiele aus Hessen, Rheinland-Pfalz und dem Saarland; Nienaber, B., Roos, U., Eds.; Selbstverlag: Hannover, Germany, 2015; pp. 131-135.

148. Kühne, O.; Weber, F. Conflicts and negotiation processes in the course of power grid extension in Germany. Landsc. Res. 2018, 43, 529-541. [CrossRef]

(C) 2020 by the author. Licensee MDPI, Basel, Switzerland. This article is an open access article distributed under the terms and conditions of the Creative Commons Attribution (CC BY) license (http://creativecommons.org/licenses/by/4.0/). 